\title{
フェノール類から多置換芳香族化合物の効率的合成
}

\author{
井川貴詞
}

\section{Efficient Synthesis of Multisubstituted Aromatic Compounds from Phenol Derivatives}

\author{
Takashi Ikawa \\ Graduate School of Pharmaceutical Sciences, Osaka University; 1-6 Yamadaoka, Suita, Osaka 565-0871, Japan.
}

(Received June 30, 2014)

\begin{abstract}
Phenols are abundant in nature and diverse phenols are readily available commercially at low cost. Thus, phenols can be used as the raw materials for the synthesis of valuable multisubstituted aromatic compounds by the direct activation of phenolic hydroxyl groups ( $\mathrm{C}-\mathrm{O}$ bond activation), followed by substitutions with other substituents. Although the derivatization of phenolic hydroxyl groups to sulfonates, such as triflates, nonaflates, tosylates and mesylates, followed by the transition-metal-catalyzed coupling reactions has been extensively investigated for this purpose, the direct $\mathrm{C}-\mathrm{O}$ bond activation of phenols for subsequent functional group transformation has been a long-standing challenge in modern organic synthesis. In this review, I have summarized my recent studies on the formal direct $\mathrm{C}-\mathrm{O}$ bond activation of phenols using nonafluorobutanesulfonyl fluoride (NfF) for the synthesis of multisubstituted aromatics. I have focused on the dual use of NfF, a less expensive commercially available reagent, including the tentative formation of highly reactive nonaflates from phenols and the use of the liberated fluoride ion as a nucleophile to promote the reactions of nonaflates. The following four topics are discussed: 1) palladium-catalyzed coupling reactions of phenols, 2) novel preparation of benzynes from 2-silylphenols, 3) synthesis of fluorinated aromatic compounds via the formation of benzynes, and 4) Hiyama coupling of (tert-butyldimethylsilyl) arenes activated by internal phenolic hydroxyl groups.
\end{abstract}

Key words — phenol; $\mathrm{C}-\mathrm{O}$ bond activation; palladium-catalyzed coupling; fluoride ion; nonafluorobutanesulfonate; multisubstituted aromatic compound

\section{1. はじめに}

ベンゼン環に直結した水酸基を有するフェノール 誘導体は，多くの生物活性天然物中に含まれる部分 構造であるとともに, 合成医薬品や機能性分子とし ても幅広く利用される（Fig. 1).1）また，フェノー 儿類は安価に入手可能な合成原料としても利用可能 であることから，フェノール類の変換反応は医薬品 や有機材料の開発において極めて重要な役割を果た す。しかし, 従来法ではフェノール性水酸基を保護 した状態で芳香環上を官能基化するのが一般的で あった (単純な求電子置換反応は除く). 最近では, 新しい遷移金属触媒反応を用いることによって，水 酸基を保護することなく, フェノール類の芳香環

The author declares no conflict of interest.

大阪大学大学院薬学研究科薬品製造化学分野（T5650871 大阪府吹田市山田丘 1-6)

e-mail: ikawa@phs.osaka-u.ac.jp

本総説は, 平成 25 年度日本薬学会東海支部学術奨励賞 の受賞を記念して記述したものである.
$\mathrm{C}-\mathrm{H}$ 結合を位置選択的に官能基化できるように なってきた. ${ }^{2-11)}$

一方，フェノール性水酸基を他の官能基へと変換 することによって，新たな多置換芳香族化合物を合 成する手法の開発研究も近年，活発に行われてい る. 12-25) 中でも，フェノール性水酸基をスルホナー ト化した，トリフラート12) 又はノナフラート, 13)さ らにはメシラート14)やトシラート15) 2 のパラジウム 触媒的カップリング反応は，フェノール性水酸基を 2 段階で様々な官能基へと変換する極めて有力な手 法である (Scheme 1)。しかし，この種の方法では ステップ数が増える上にアトムエコノミーが悪いこ とが最大の欠点である. 一方最近, フェノール性水 酸基をスルホナート化することなく，水酸基を直接 変換する手法の報告例も増えつつある. ${ }^{16-25)}$ しか し，それぞれの変換反応は基質が大幅に限定されて いるのが現状である。以上のような背景の中で，一 般性あるフェノール性水酸基の直接変換法の開発が 待ち望まれていた。 
<smiles>N[C@@H](Cc1cc(I)c(Oc2cc(I)c(O)c(I)c2)c(I)c1)C(=O)O</smiles>

thyroxin

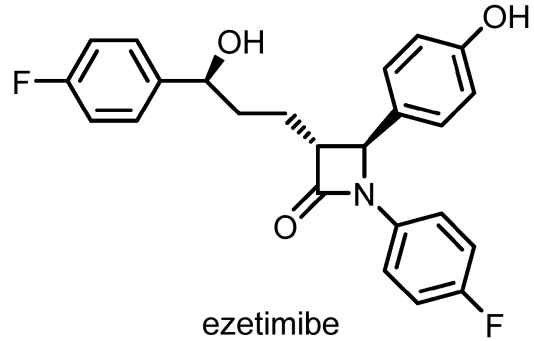

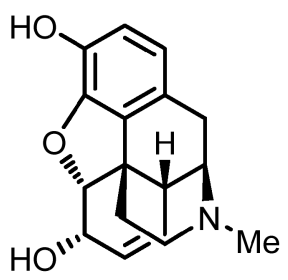

morphine<smiles>Oc1cc(O)c2c(c1)O[C@H](c1ccc(O)c(O)c1)[C@H](O)C2</smiles>

catechin<smiles>CN(C)CC(c1ccc(O)cc1)C1(O)CCCCC1</smiles>

desvenlafaxine

Fig. 1. Biologically Active Compounds Containing Phenolic Hydroxyl Group

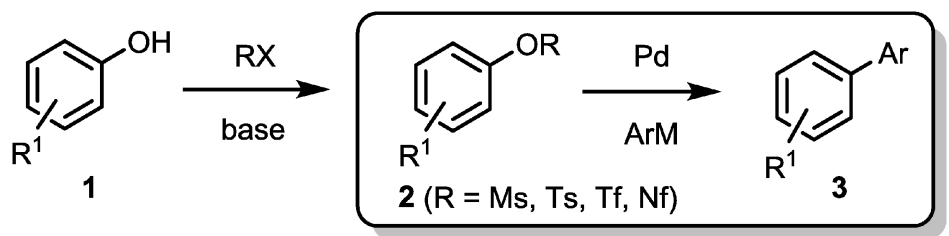

Scheme 1. Stepwise Synthesis of Biaryls 3 through Sulfonylation of Phenols $\mathbf{1}$ and Their Pd-catalyzed Couplings of Sulfonates 2 [Ms $\left.=\mathrm{SO}_{2} \mathrm{Me}, \mathrm{Ts}=\mathrm{SO}_{2} \mathrm{C}_{6} \mathrm{H}_{4}(p-\mathrm{Me}), \mathrm{Tf}=\mathrm{SO}_{2} \mathrm{CF}_{3}, \mathrm{Nf}=\mathrm{SO}_{2}\left(\mathrm{CF}_{2}\right)_{3} \mathrm{CF}_{3}\right]$

フェノール性水酸基の優れたノナフラート化剂で あるノナフルオロブタンスルホニルフルオリド (nonafluorobutanesulfonyl fluoride; NfF) 4 は, 安 価かつ安定で有用な反応剤である. ${ }^{26,27)}$ この試薬 $\mathbf{4}$ は，脂肪族アルコールとの反応にも利用されてお り，この場合，4から放出されたフッ素アニオンが ノナフリルオキシ基（NfO 基）の背面から求核攻 撃するため，ノナフラート化で反応は停止せず，一 挙にフッ素化まで進行することが知られている (Scheme 2). ${ }^{28)}$ 本アルコールのフッ素化反応は, 試 薬の特性が存分に生かされた優れた変換反応と言え る.

NfF 4 を用いるフェノール性水酸基のノナフラー 卜化反応は, 数多く報告されているにもかかわら ず，その際に生じたフッ素アニオンを有効に利用し た反応は，筆者らによる報告以前には全く報告例が なかった。筆者らは，4 による二重活性化に基づく 多置換芳香族化合物合成法として，1）フェノール 類の鈴木カップリング反応, ${ }^{29)}$ 2) フェノール類か

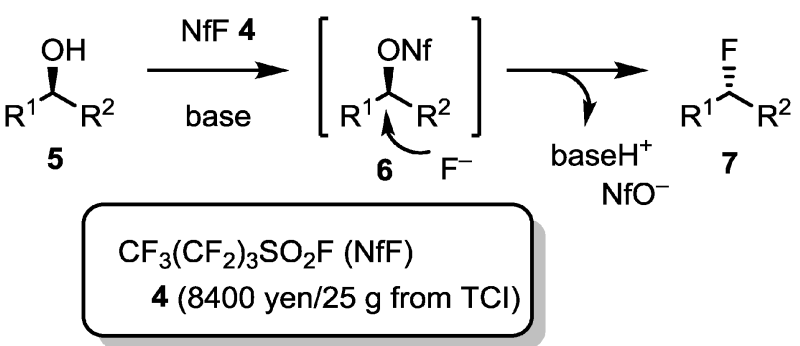

Scheme 2. In-situ Nonaflylation of Alcohols 5 using NfF 4 for the Synthesis of Alkylfluorides 7

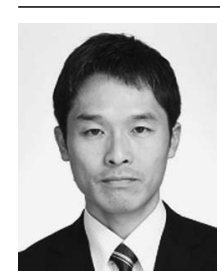

井川貴詞
大阪大学大学院薬学研究科 $\cdot$ 助教 博 士 (薬学). 2005 年岐阜薬科大学大学 院薬学研究科博士後期課程修了, 同年 米国 MIT 化学科博士研究員 (上原記念 生命科学財団ポストドクトラルフェ ロー), 2007 年静岡県立大学薬学部・ 助教を経て 2013 年 6 月より現職. 2008 年有機合成化学協会ダイセル研究企画 賞, 2013 年日本薬学会東海支部学術奨 励賞. 


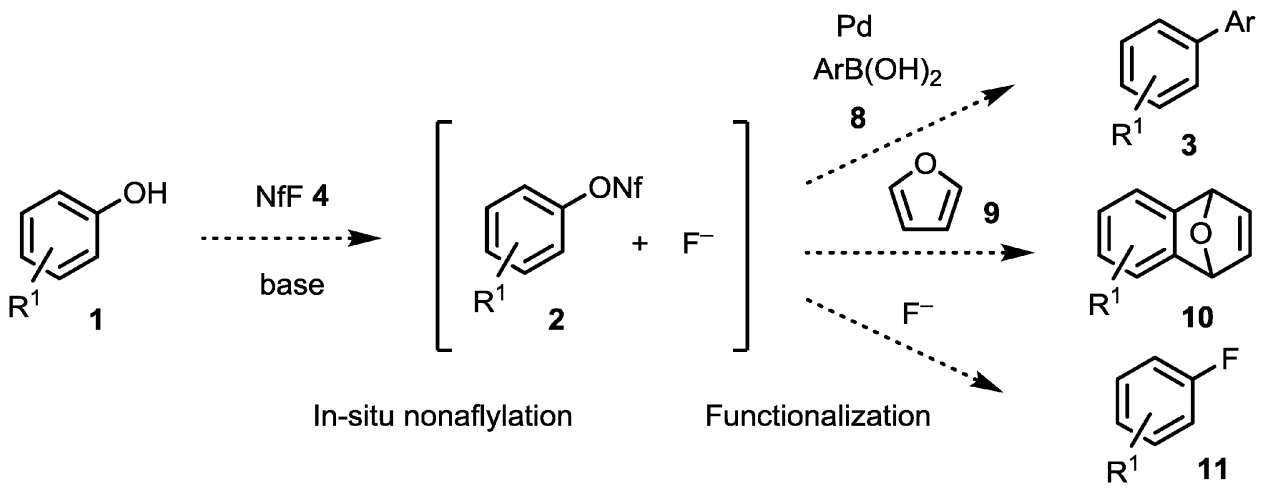

Scheme 3. In-situ Nonaflylation of Phenols 1 Using NfF 4 for the Synthesis of Multisubstituted Aromatics 3, 10, 11

Table 1. One-pot Suzuki Couplings of Phenol Derivatives 1 with Boronic Acids 8 Using NfF 4

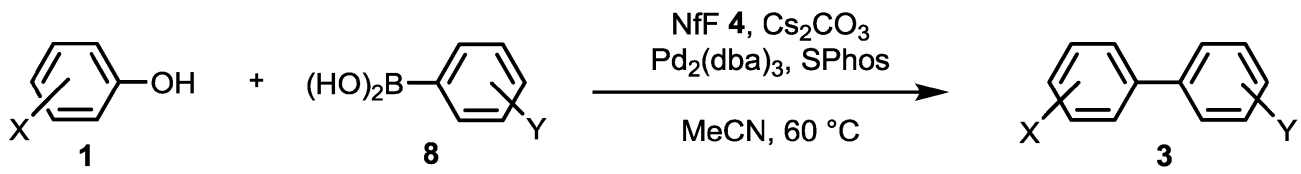

Entry

a Isolated yield.

らのベンザインの発生, ${ }^{30)} 3$ 3) 芳香環上のフッ素化 反応 ${ }^{31)}$ の開発に成功した (Scheme 3$)$. 本総説で は，上記 3 種の反応と合わせて，筆者らの開発した 4）分子内フェノール性水酸基によって活性化され た極めて嵩高い TBDMS 置換アレーンの檜山カッ

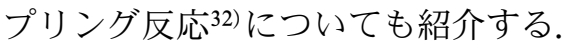

2. フェノール性水酸基の in situ 活性化を利用 する多置換ビアリール類合成 ${ }^{29)}$

鈴木カップリング反応は，パラジウム触媒存在 下，芳香族ホウ素化合物を基質として，ビアリール 化合物を触媒的に合成する有力な反応である. ${ }^{33)}$ 本 反応は，高配位ホウ素の形成によりトランスメタル
化を促進させるために，フッ素アニオンなどのアニ オン種共存下にて反応を行うことが多い. 筆者らは, $\mathrm{NfF} 4$ を用いたフェノール類のノナフラート化の際 に生じるフッ素アニオンをボロン酸の活性化に利用 するドミノ型鈴木カップリング反応を開発した。 フェノール 1 とボロン酸 8,4 のアセトニトリル溶 液中にパラジウム触媒と塩基存在下, $60^{\circ} \mathrm{C}$ で加熱 撹汼すると 1 のノナフラート化とカップリング反応 が一挙に進行し，ビアリール 3 が得られる，本反応 は，幅広い基質一般性があり， 1 及び 8 の芳香環上 に電子供与基, 電子求引性基のいずれが存在しても 問題なく進行する（Table 1)。また，脂肪族水酸基 
a) Sonogashira coupling

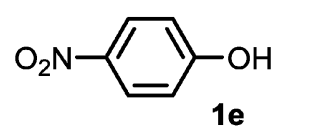

b) Stille coupling

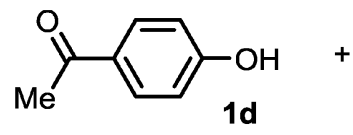

c) Buchwald-Hartwig amination

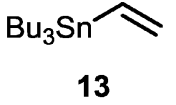

13

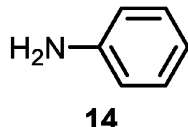

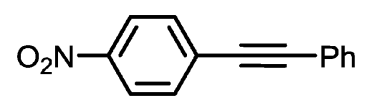

$15,95 \%$

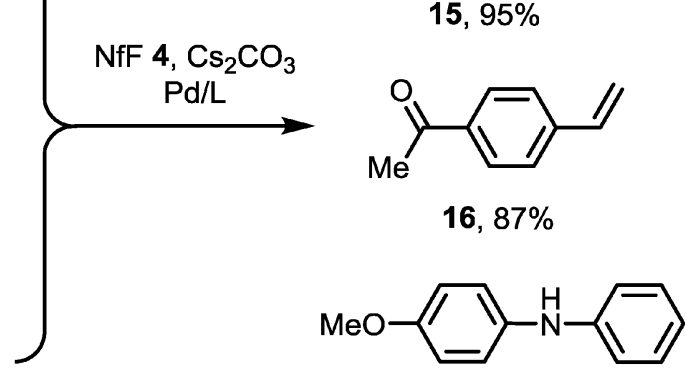

$17,90 \%$

Scheme 4. Various Couplings of Phenol Derivatives 1d-1f

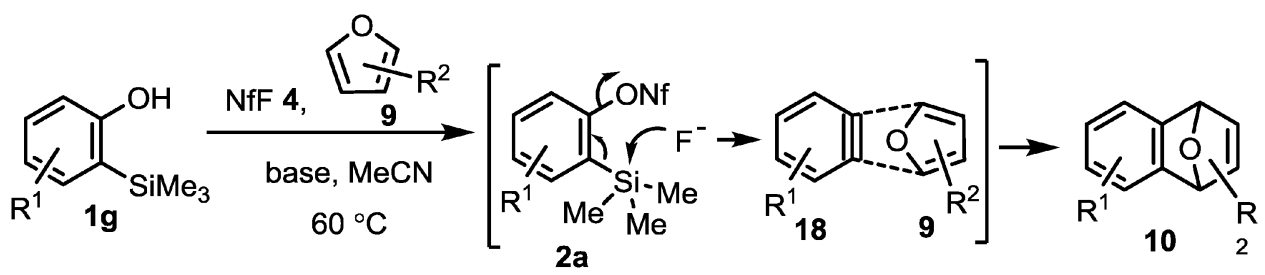

Scheme 5. One-pot Synthesis of $\mathbf{1 0}$ by Diels-Alder Reactions of Furans $\mathbf{9}$ with Benzynes $\mathbf{1 8}$ Generated from 2-Silylphenols $\mathbf{1 g}$ Using $\mathrm{NfF} 4$

が分子内に存在してもノナフラート化はフェノール 性水酸基において選択的に進行し，カップリング生 成物 3b が得られる（Entry 2).

鈴木カップリングと同様，アセチレン 12 との薗 頭カップリング，アルケニルスズ 13 との Stille カップリング，アミン $\mathbf{1 4}$ との Buchwald-Hartwig アミノ化反応にも本法を適用することができる (Scheme 4)。なお，芳香族アミン 14 共存下でも フェノール 1 のノナフラート化とカップリング反応 は選択的に進行し，14 のアミド化は全く進行しない.

3. 2-シリルフェノールを前駆体とするベンザイ ン発生と多置換芳香族化合物合成 ${ }^{30)}$

ベンザインは，その高い反応性ゆえに多様な変換 反応が可能である. ${ }^{34-36)}$ したがって，ベンザインを フェノール類から発生させることができれば，フェ ノール類の新しい変換法として有力な手法となる. 筆者は，フェノールから容易に合成できるオルトト リメチルシリルフェノール $1 \mathrm{~g}$ を基質とするベンザ イン 18 発生法を開発した (Scheme 5)。本法では, $1 \mathrm{~g}$ のアセトニトリル溶液中に NfF 4 を塩基存在下 で反応させることで，フェノール性水酸基のノナフ ラート化が進行し，2a が系内で発生，同時に 4 か ら生じたフッ素アニオンはオルト位のシリル基を攻 撃することによって 18 が発生する。生じた 18 は, 反応系中のフラン 9 と環化付加することで $\mathbf{1 0}$ が得 られる。

$1 \mathrm{~g}$ から本法によって発生させたベンザイン 18 は 多様な反応剂との反応に適用可能である（Scheme 6). 例えば，アジド 19 との $(3+2)$ 環化付加反応,

アミン 20 の求核付加反応, 銅触媒を用いる 18 とア セチレン 21, 塩化アリル 22 の 3 成分連結反応は, 首尾よく進行し多様な芳香族化合物 23-25 乞 変換 することができる.

本ベンザイン発生法は，2-ブロモフェノール $1 \mathrm{~h}$ からの 5 段階ワンポット反応への適用が可能である (Scheme 7)。まず，1h をへキサメチルジシラザン によるシリル化後，ブチルリチウムによるシリル基 の転移によって系内にリチウムアルコキシド 27 を 発生させる.ここへ NfF 4 とフラン 9a, 炭酸セシ ウム, クラウンエーテルを加えると, ベンザイン 18a が発生したことを示す環化付加生成物 10a を与 える。 


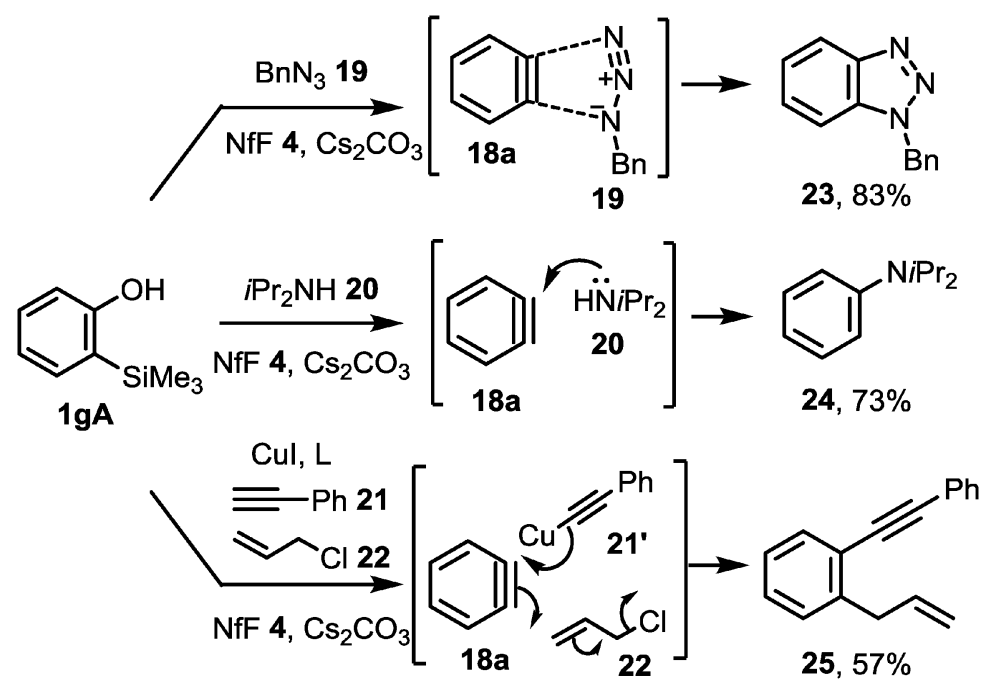

Scheme 6. Synthesis of Various Compounds 23-25 from $\operatorname{1gA}$

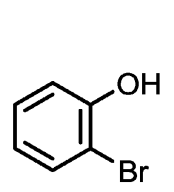

$1 \mathrm{~h}$

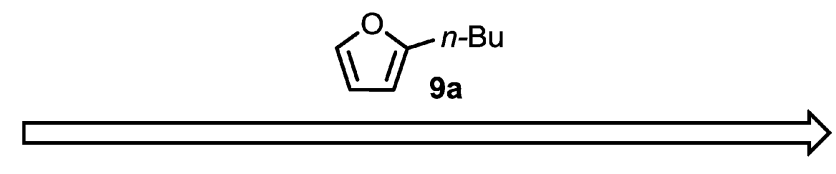

5-step one-pot reaction<smiles>CC(C)(C)C12C=CC(O1)c1ccccc12</smiles>

$10 a, 43 \%$

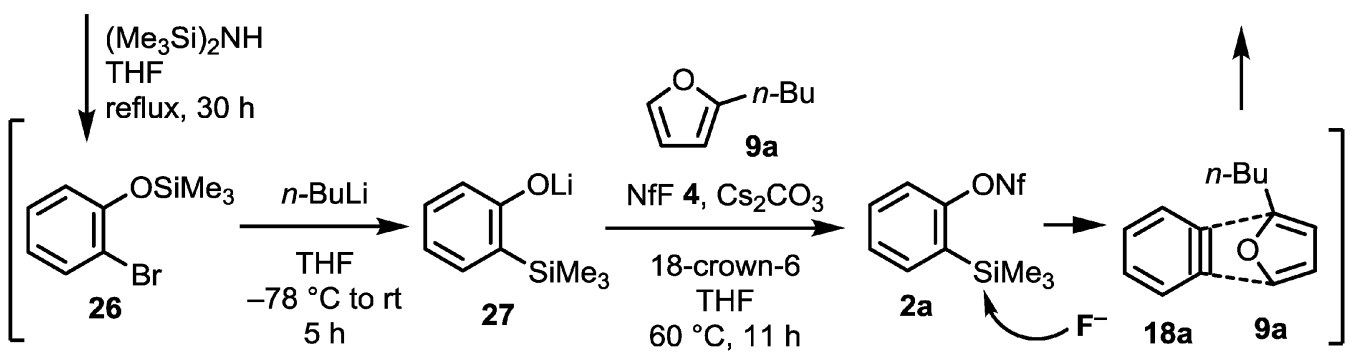

Scheme 7. 5-Step One-pot Synthesis of 10a from 2-Bromophenol 1h

4. フェノール性水酸基の活性化による芳香族 フッ素化合物合成31)

分子内にフッ素原子を有する天然物はほとんど存 在しないが，多くの低分子医薬品は，芳香環上に フッ素原子を有している，しかし，芳香環にフッ素 を効率よく導入する手法は少なく，反応条件も過酷 であることが多い。したがって，芳香族フッ素化合 物合成法は医薬品開発において極めて重要な研究課 題である. ${ }^{21)}$ 最近，取扱い容易なフッ素アニオンを 用いる有力なフッ素導入法が報告されつつある が, 37-39) いまだ高い反応温度が必要であることなど 改善の余地がある。筆者は, 先に開発したオルトシ リルフェノール $1 \mathrm{~g}$ からのベンザイン発生法を用い て, ベンザイン 18 への求核付加反応による芳香族 フッ素化合物合成に成功した（Table 2)。すなわ
ち，オルトシリルフェノールのアセトニトリル溶液 中にフッ化セシウム存在下, NfF 4 を加えて摚拌後, $\mathrm{Bu}_{4} \mathrm{NF}(t-\mathrm{BuOH})_{4},{ }^{40)}$ クラウンエーテルを加えると, 18 の発生とフッ素化反応が一挙に進行し，芳香族 フッ素化合物 $\mathbf{1 1}$ が生成する。この方法は，フェ ノール性水酸基のオルト位に嵩高い置換基を有する 基質の場合には，系中でのノナフラート化が全く進 行せず，目的化合物 $\mathbf{1 1}$ を合成することができない.

代替法として，オルトシリルフェノール $1 \mathrm{~g}$ のノ ナフラート 2a をあらかじめ調製し，フッ素化を行 う手法を開発した（Table 3)。この手法では，嵩高 い置換基がフェノール性水酸基のオルト位に存在し ても反応は進行し（Entry 3), 先の手法より工程数 は一工程長くなるものの，より幅広い基質適用性を 有している．筆者らの開発した相補的な 2 つの手法 
Table 2. One-pot Synthesis of Aromatic Fluorides 11 from 2-Silylphenols 19

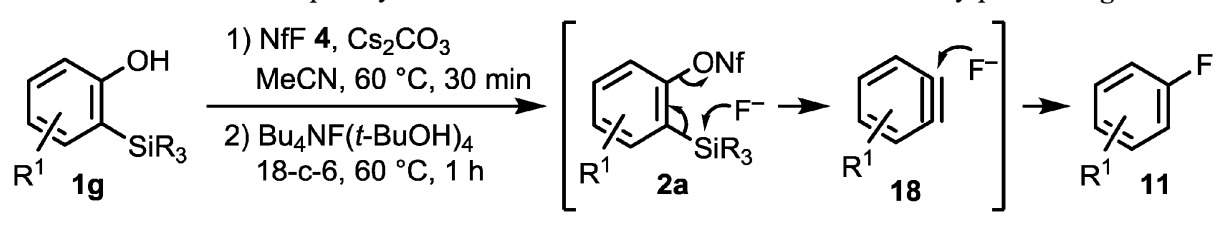

Entry

a Isolated yield.

Table 3. Stepwise Synthesis of Aromatic Fluorides 11 from 2-Silylphenols 19

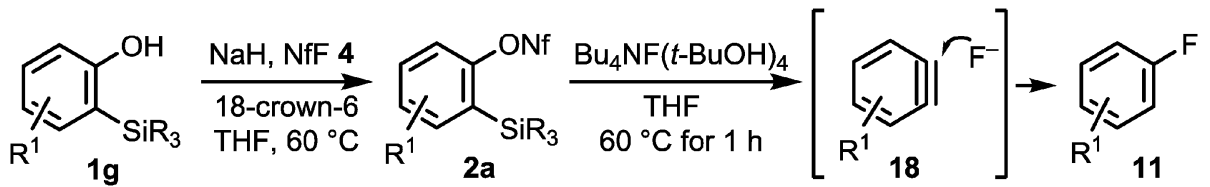

Entry

a Isolated yield. ${ }^{\mathrm{b}}$ Determined by GC. 


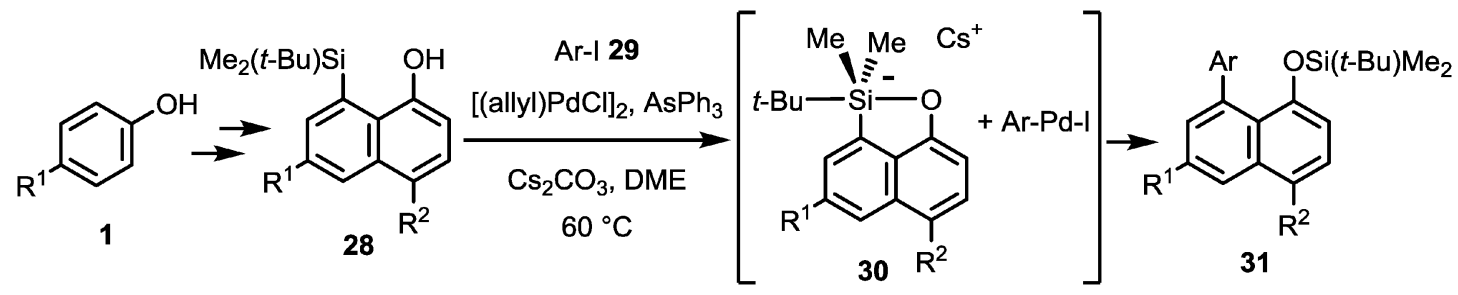

Scheme 8. Hiyama Couplings of 8-(tert-Butyldimethylsilyl)-1-naphthols 28 Prepared from 1
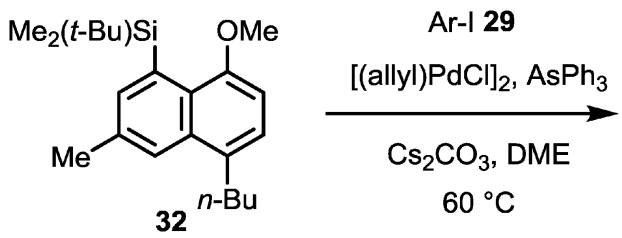

Scheme 9. Reactivity of Methyl Ether 32 under Coupling Conditions

は，フェノール類 1 を原料とする新しい芳香族フッ 素化合物合成法として有用である.

5. 分子内フェノール性水酸基を活用する TBDMS 基活性化型多置換ビアリール合成 ${ }^{32}$

芳香族ケイ素化合物のカップリング反応として広 く知られる檜山カップリングは，ビアリール類を合 成するための環境負荷の低い有力な反応の 1 つであ る. ${ }^{41,42)}$ しかし，このカップリング反応を達成する ためには，ケイ素上にフッ素や酸素などの電子陰性 度の大きな原子の置換が必要な場合がほとんどであ り, 安定で取扱い容易なトリアルキルシランの檜山 カップリングは極めて困難とされている. ${ }^{43,44)}$ 筆者 らは，分子内のフェノール性水酸基を利用すること で，極めて嵩高い tert-butyldimethylsilyl 基 （TBDMS 基）を活性化し，初めてその檜山カップ リングに成功した（Scheme 8)。本カップリング反 応は，多様なヨウ化アリール 29 及び 8-ヒドロキシ ナフチルシラン 28 が適用可能であり，一般性ある ビアリール類 31 の合成法として有用である，本反 応において，原料 28 の芳香環上に置換した TBDMS 基が，生成物 31 では，ペリ位酸素上に転 移しており，高配位中間体 $\mathbf{3 0}$ の生成が示唆された.

また，28 のメチルエーテル 32 を基質として Scheme 8 と全く同じ反応条件下, 長時間反応を 行っても，原料回収となる (Scheme 9)。この実験 結果からも, 本反応には分子内フェノール性水酸基 による隣接基関与，すなわち高配位中間体 $\mathbf{3 0}$ の形
成が必須であると言える.

分子内オキシアニオンのキレート化を利用する檜 山カップリング反応は，他の研究者らによっても報 告されており, ${ }^{45-49)}$ 特に檜山，中尾らによって開発 された手法は，基質一般性が高く優れた方法である (Scheme 10). ${ }^{47-49)}$ すなわち，オルト位にヒドロキ シメチル基を有するアリールシラン 33 とヨウ化ア リール 29 をパラジウム触媒存在下，反応させると ケイ素上に置換した $\mathrm{R}^{1}$ が選択的にトランスメタル 化し, ビアリール化合物へと変換することが可能で ある. また， シラン 33 の構造を一部改良すること によって $\mathrm{R}^{1}$ がアルキル基の場合でもトランスメタ ル化反応は効率的に進行し, 環境負荷が小さく, 一 般性ある 29 とのアリールーアルキルクロスカップリ ング反応が開発された. ${ }^{48)}$

上記に示した檜山，中尾らによる手法は，筆者ら の手法と類似の 5 員環高配位中間体 36 を形成する 檜山カップリングであるが，筆者らの報告した反応 とは切断される炭素ーケイ素結合が異なっている (Fig. 2)．すなわち，檜山らによる中間体 $\mathbf{3 6}$ の場 合，切断される結合は高配位酸素の対面に置換する $\mathrm{R}^{1}$ とケイ素とのアピカル結合であるのに対し，筆 者らの中間体 $\mathbf{3 0}$ の場合, エクアトリアル結合が切 断されヨウ化アリール 29 とのカップリング反応が 進行する点で，2つの檜山カップリング反応は大き く異なる.

\section{6. おわりに}

筆者らは， NfF を用いてフェノール性水酸基を 反応系中で活性化し，水酸基を別の官能基へ変換す る新しい多置換芳香族化合物合成法を確立した。9 個ものフッ素原子を含む NfF は，意外にもパーフ ルオロアルカンスルホナート化剂の中で最も安価か つ実験台上でも安定な試薬であり，その特徵を最大 限に生かした筆者らの手法は，経済的にも有機合成 化学的にも有用な手法である。.また，フェノール類 


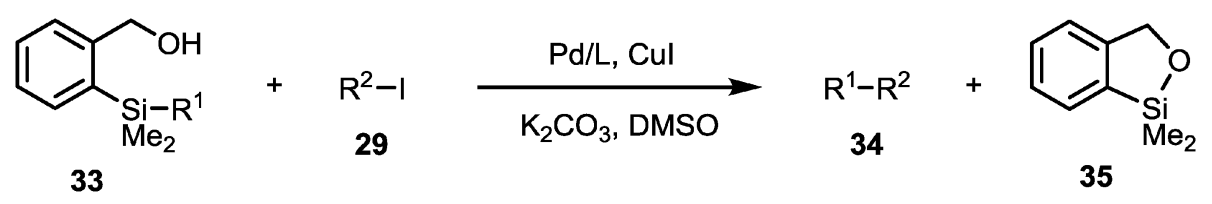

Scheme 10. Hiyama and Nakao's Couplings of Tetraorgano Silane Reagents 33

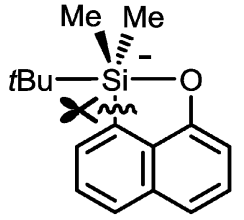

Our intermediate $\mathbf{3 0}$

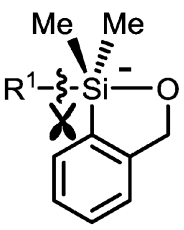

Hiyama's intermediate 36
Fig. 2. Difference between Our Intermediate $\mathbf{3 0}$ and Hiyama's One 36

は天然物中に幅広く存在しており，容易に入手可能 であることから，本法を用いれば，多様性ある化合 物ライブラリーを簡便に構築可能である. 今後, 本 法が医薬品開発において重要な役割を果たすときが 来るのを期待したい.

謝辞本研究は, 静岡県立大学薬学部で行われ たものであり，終始ご指導を賜りました大阪大学大 学院薬学研究科教授 (元静岡県立大学薬学部教授) 赤井周司先生に心より感謝申し上げます。また，本 研究を遂行するにあたりご協力頂いた，高柳祥一博 士，高木 晃博士を始めとする多くの学生に感謝致 します。なお, 本研究は, 科学研究費補助金, 上原 記念生命科学財団, 浜松科学技術研究所, 有機合成 化学協会ダイセル化学工業研究企画賞, 中部電気利 用基礎研究振興財団の援助によつて行われたもので あり，ここに御礼申し上げます。

\section{REFERENCES}

1) Tyman J. H. P., "Synthetic and Natural Phenols," Elsevier, Amsterdam, 1996.

2) Trost B. M., Toste F. D., J. Am. Chem. Soc., 118, 6305-6306 (1996).

3) Bedford R. B., Coles S. J., Hursthouse M. B., Limmert M. E., Angew. Chem. Int. Ed., 42, 112-114 (2003).

4) Ciana C.-L., Phipps R. J., Brandt J. R., Meyer F.-M., Gaunt M. J., Angew. Chem. Int. Ed., 50, 458-462 (2011).

5) Lee D.-H., Kwon K.-H., Yi C. S., J. Am.
Chem. Soc., 134, 7325-7328 (2012).

6) Truong T., Daugulis O., Chem. Sci., 4, 531535 (2013).

7) Sharma U., Naveen T., Maji A., Manna S., Maiti D., Angew. Chem. Int. Ed., 52, 1266912673 (2013).

8) Kuram M. R., Bhanuchandra M., Sahoo A. K., Angew. Chem. Int. Ed., 52, 4607-4612 (2013).

9) Zhu R., Wei J., Shi Z.-J., Chem. Sci., 4, 3706-3711 (2013).

10) Huang Z., Jin L., Feng Y., Peng P., Yi H., Lei A., Angew. Chem. Int. Ed., 52, 7151-7155 (2013).

11) Zhang X.-S., Li Z.-W., Shi Z.-J., Org. Chem. Front., 1, 44-49 (2014).

12) Ritter K., Synthesis, 735-762 (1993).

13) Han X., Stoltz B. M., Corey E. J., J. Am. Chem. Soc., 121, 7600-7605 (1999).

14) So C. M., Kwong F. Y., Chem. Soc. Rev., 40, 4963-4972 (2011).

15) Li B.-J., Yu D.-G., Sun C.-L., Shi Z.-J., Chem. Eur. J., 17, 1728-1759 (2011).

16) Kang F.-A., Sui Z., Murray W. V., J. Am. Chem. Soc., 130, 11300-11302 (2008).

17) Ackermann L., Mulzer M., Org. Lett., 10, 5043-5045 (2008).

18) Luo Y., Wu J., Tetrahedron Lett., 50, 21032105 (2009).

19) Luo Y., Wu J., Tetrahedron, 65, 6810-6814 (2009).

20) Yu D.-G., Li B.-J., Zheng S.-F., Guan B.-T., Wang B.-Q., Shi Z.-J., Angew. Chem. Int. Ed., 49, 4566-4570 (2010).

21) Tang P., Wang W., Ritter T., J. Am. Chem. Soc., 133, 11482-11484 (2011).

22) Yu D.-G., Shi Z.-J., Angew. Chem. Int. Ed., 50, 7097-7100 (2011).

23) Chen G.-J., Huang J., Gao L.-X., Han F.-S., Chem. Eur. J., 17, 4038-4042 (2011).

24) Čerňová M., Pohl R., Klepetářová B., Hocek M., Synlett, 23, 1305-1308 (2012). 
25) Ackermann L., Pospech J., Potukuchi H. K., Org. Lett., 14, 2146-2149 (2012).

26) Vorbrüggen H., Synthesis, 1165-1174 (2008).

27) Högermeier J., Reissig H.-U., Adv. Synth. Catal., 351, 2747-2763 (2009).

28) Bennua-Skalmowski B., Vorbrüggen H., Tetrahedron Lett., 36, 2611-2614 (1995).

29) Ikawa T., Saito K., Akai S., Synlett, 23, 22412246 (2012).

30) Ikawa T., Nishiyama T., Nosaki T., Takagi A., Akai S., Org. Lett., 13, 1730-1733 (2011).

31) Ikawa T., Masuda S., Nishiyama T., Takagi A., Akai S., Aust. J. Chem., 67, 475-480 (2014).

32) Akai S., Ikawa T., Takayanagi S., Morikawa Y., Mohri S., Tsubakiyama M., Egi M., Wada Y., Kita Y., Angew. Chem. Int. Ed., 47, 76737676 (2008).

33) Miyaura N., Suzuki A., Chem. Rev., 95, 2457-2483 (1995).

34) Dyke A. M., Hester A. J., Lloyd-Jones G. C., Synthesis, 24, 4093-4112 (2006).

35) Sanz R., Org. Prep. Proced. Int., 40, 215-291 (2008) .

36) Tadross P. M., Stoltz B. M., Chem. Rev., 112, 3550-3577 (2012).

37) Watson D. A., Su M., Teverovskiy G., Zhang Y., García-Fortanet J., Kinzel T., Buchwald S. L., Science, 325, 1661-1664 (2009).
38) "Fluorine in Medicinal Chemistry and Chemical Biology,", ed. by Ojima I., Wiley-Blackwell, Chichester, 2009.

39) Nemoto H., Nishiyama T., Akai S., Org. Lett., 13, 2714-2717 (2011).

40) Kim D. W., Jeong H.-J., Lim S. T., Sohn M.H., Angew. Chem. Int. Ed., 47, 8404-8406 (2008).

41) Nakao Y., Hiyama T., Chem. Soc. Rev., 40, 4893-4901 (2011).

42) Denmark S. E., Ober M. H., Aldrichimica Acta, 36, 75-85 (2003).

43) Trost B. M., Machacek M. R., Ball Z. T., Org. Lett., 5, 1895-1898 (2003).

44) Sahoo A. K., Oda T., Nakao Y., Hiyama T., Adv. Synth. Catal., 346, 1715-1727 (2004).

45) Taguchi H., Ghoroku K., Tadaki M., Tsubouchi A., Takeda T., J. Org. Chem., 67, 8450-8456 (2002).

46) Shindo M., Matsumoto K., Shishido K., Synlett, 176-178 (2005).

47) Nakao Y., Imanaka H., Sahoo A. K., Yada A., Hiyama T., J. Am. Chem. Soc., 127, 6952-6953 (2005).

48) Nakao Y., Takeda M., Matsumoto T., Hiyama T., Angew. Chem. Int. Ed., 49, 4447-4450 (2010).

49) Nakao Y., Hiyama T., Yuki Gosei Kagaku Kyokai Shi, 69, 1221-1230 (2011). 